\title{
Fakta dan Fungsi Sosial Novel Trah Karya atas S Danusubroto
}

\author{
Marientha Hera Pratiwi Abani ${ }^{\star 1}$ \\ 1,2Program Studi Sastra Jawa, Fakultas Bahasa dan Seni, Universitas Negeri Semarang
}

Info Artikel

Article History:

Diajukan January 9, 2019

Diterima June, 302019

Terbit June, 302019

\section{Kata kunci:}

fakta sosial;

fungsi sosial;

sosiologi sastra;

novel Trah

\begin{abstract}
Abstrak
Novel Trah karya Atas S. Danusubroto menceritakan kehidupan pelacur. Kebiasaan Danusubroto menceritakan kondisi di lingkungan sekitarnya. novel ini mengangkat permasalahan yang cukup detail. Tujuan penelitian ini untuk mengetahui fungsi Danusubroto menulis novel Trah ditinjau dari konteks sosial pengarang dan fakta sosial. Penelitian menggunakan pendekatan sosiologi sastra, dan metode dialektik. Data yang digunakan berupa kata atau frasa yang mengandung fakta dan fungsi sosial, biografi pengarang, dan fakta sosial di luar teks yang berkaitan dengan latar penulisan novel Trah. Metode pengumpulan data menggunakan teknik baca, catat, dan studi pustaka, sedangkan metode analasis data menggunakan metode deskriptif analitik. Hasil penelitian novel Trah ditulis sebagai bentuk kritik penulis terhadap pemerintah sebagai imbas dari krisis ekonomi tahun 2008. Novel Trah berisi kritik terhadap pola pikir masyarakat yang cenderung mengandalkan harta warisan orang tuanya. Kritik-kritik tersebut disampaikan dalam bentuk dialog antar tokoh, dan didasarkan dari konteks sosial pengarang serta fakta sosial. Fakta-fakta sosial yang terdapat dalam novel Trah adalah masalah kemiskinan, pengangguran, pelacuran, dan harta warisan.
\end{abstract}

\section{PENDAHULUAN}

Novel Trah karya Atas S. Danusubroto menceritakan kehidupan Tilarsih, bekas wanita penghibur. Ia dikucilkan oleh masyarakat di desanya. Bagi masyarakat desa wanita penghibur atau pelacur masih dipandang negatif. Hal inilah yang membuat Tilarsih mengalami *

E-mail:marienthahera@gmail.com

Alamat: Gedung B-8 Fakultas Bahasa dan Seni

Universitas Negeri Semarang

Kampus Sekaran, Gunungpati, Semarang 50229 banyak masalah dalam mengembalikan nama baik dirinya. Meskipun begitu novel ini mendapat Anugerah Sastra Rancage tahun 2009.

Atas S. Danusubroto merupakan salah satu pengarang yang produktif di bidang sastra. Selain itu, ia juga aktif dalam dunia jurnalisitik. Dalam novel Trah, Danusubroto mencantumkan nama-nama daerah di Jawa Tengah yang membuat ceritanya seperti diangkat dari kisah nyata. Kebiasaan Danusubroto menuliskan nama tempat yang diketahui secara pasti, membuat novel ini mengangkat permasalahan-permasalahan sosial 
yang ada di masyarakat dengan cukup detail. Menurut Ratna (2010:324), dalam banyak hal justru karya sastra lebih berhasil mengungkapkan masalah-masalah sosial sebab karya sastra melukiskannya melalui bahasa metaforis konotatif. Hal ini sejalan dengan teks sastra yang merupakan institusi sosial yang membicarakan masalah-masalah sosial (Supriyanto 2008:8).

Novel Trah ditulis pada tahun 2008, dimana sedang terjadi krisis ekonomi global yang disebabkan oleh krisis ekonomi Amerika Serikat. Krisis ini menyebar ke negara-negara lain termasuk Indonesia dan berdampak pada nilai ekspor yang menurun. Dampak lainnya yaitu semakin banyak perusahaan yang mengurangi jumlah tenaga kerjanya. Unsur budaya Jawa juga cukup kental digambarkan Atas dalam novel Trah yang berkaitan dengan kehidupan masyarakat pedesaan Jawa yang sudah mengalami modernisasi tetapi masih berpegang pada budaya Jawa. Pandangan masyarakat kepada bekas wanita penghibur, yang merendahkan dan menghina bertolak belakang dengan budaya Jawa yang halus, sopan, penuh etika dan juga tata krama. Hal-hal yang memang dianggap tabu untuk diungkapkan secara langsung disampaikan secara konotatif. Karena masyarakat Jawa menganut prinsip kerukunan dan prinsip hormat, sehingga segala bentuk interaksi konflik-konflik terbuka harus dicegah (Suseno 2003:69).

Fakta-fakta tersebut membuat novel ini menarik untuk diteliti karena novel ini mendapatkan penghargaan karena kultur budayanya, sedangkan sikap masyarakat dalam cerita tersebut bertentangan dengan etika Jawa. Kedua ditinjau dari segi bagaimana Atas menggambarkan fakta-fakta sosial yang ada di lingkungan sekitarnya ke dalam cerita. Bisa jadi novel ini merupakan bentuk kritik terhadap pemerintah. Meskipun karya sastra dianggap sebagai cermin masyarakat, tetapi dalam menuliskan fakta sosial, objektivitas pengarang juga berpengaruh. Apakah dalam penulisan novel Trah Atas S. Danusubroto berhasil membuktikan keprofesonalitasannya sebagai seorang pengarang.

Pemikiran ini sejalan dengan pendapat Ian Watt dalam esainya "Literature and Society" yang membicarakan hubungan timbal balik antara sastrawan, sastra, dan masyarakat. Hubungan tersebut dipengaruhi oleh tiga hal, yang pertama konteks sosial pengarang. Konteks sosial pengarang dalam hal ini berhubungan dengan posisi sosial sastrawan dalam masyarakat dan kaitannya dengan masyarakat pembaca. Dalam pokok ini termasuk juga faktor-faktor sosial yang bisa mempengaruhi isi karya sastranya. Konteks sosial terdiri dari (a) bagaimana si pengarang mendapatkn profesi, (b) profesionalisme kepengarangan, (c) masyrakat yang dituju. Kedua sastra sebagai cermin masyarakat. Cermin berarti bayangan. Sastra adalah bayangan dari realitas sosial, dan yang ketiga fungsi sosial sastra, yang mempermasalahkan pada sejauh mana nilai sastra dipengaruhi oleh nilai sosial dan sejauh mana sastra tersebut dapat berfungsi sebagai alat penghibur sekaligus sebagai alat pendidikan bagi masyarakat pembaca. (Damono 2002: 4)

\section{METODE PENELITIAN}

Pendekatan penelitian ini menggunakan pendekatan sosiologi sastra. Sosiologi sastra merupakan suatu disiplin yang memandang teks sastra sebagai cerminan dari realitas sosial. Metode penelitian yang digunakan adalah metode dialektik, yaitu hubungan timbal balik antara karya sastra dengan realitas sosial. Sasaran penelitian ini adalah fakta dan fungsi sosial dalam novel Trah karya Atas S. Danusobroto, yang akan dianalisis menggunakan konsep Sosiologi Ian Watt. Data penelitian ini berupa kata atau frasa yang mengandung fakta dan fungsi sosial, biografi pengarang, dan fakta sosial di luar teks yang berkaitan dengan latar penulisan novel Trah. Sumber data berupa novel Trah karya Atas S. Danusubroto cetakan pertama tahun 2008, terbitan Narasi.

Metode pengumpulan data dalam penelitian ini menggunakan teknik baca, catat, dan studi pustaka. Teknik baca dalam karya ilmiah dilakukan dengan cara memberikan perhatian yang benar-benar terfokus pada objek (Ratna 2010:245). Teknik studi pustaka digunakan untuk mengumpulkan data-data dari luar novel seperti fakta sosial dan biografi pengarang. Metode analisis penelitian ini menggunakan metode deskriptif analitik. Metode deskriptif analitik dilakukan dengan cara mendeskripsikan fakta-fakta yang kemudian disusul dengan analisis. Metode gabungan yang lain, misalnya deskriptif komparatif, metode dengan cara menguraikan dan membandingkan, dan metode deskriptif induktif, metode dengan cara menguraikan yang diikuti dengan pemahaman dari dalam ke luar.

\section{HASIL DAN PEMBAHASAN}

Konteks sosial pengarang merupakan faktor yang cukup penting dalam konsep sosiologi sastra, karena sosiologi memandang hubungan timbal balik bukan hanya sekedar karya sastra dan masyarakat, tetapi juga dengan pengarang. Atas S. Danusbroto memiliki nama asli Atas Sampurno, Atas lahir di Cilacap pada tahun 1949. Pada tahun 1972 Atas menikah dengan seorang gadis dari Purwodadi, Purworejo. Dari perkawinan itu dia dianugerahi tiga orang anak (2 perempuan dan 1 laki-laki).

Atas S. Danusubroto memulai karir kepenulisannya sebagai seorang wartawan di mingguan Pelopor (1976). Sekarang ia menjadi Wakil Pemimpin Redaksi Majalah Legalitas edisi Semarang. Selain itu, bersama kawannya Atas menerbitkan majalah SD yang bernama Cerdas yang diterbitkan Dinas Pendidikan dan Kebudayaan. Atas S. Danusubroto juga memiliki banyak pengalaman berorganisasi, terutama organiasai kepengarangan. Ia pernah tergabung dalam Persada Studi Klub (PSK), Kelompok Penulis Semarang (KPS), dan Kelompok Pencinta Sastra Purworejo (Kopi Sisa).

Atas mengaku hobi menulis semenjak SMA. Nama samaran yang sering digunakan ialah Kemuning Sesele. Ia mengirimkan tulisannya (guritan, cerkak, cerbung) ke majalah Mekar Sari, Djaka Lodang, Panjebar Semangat. Pada tahun 2002 novelnya Tembang Katresnan terpilih sebagai pemenang ketiga dalam Lomba Penulisan Novel Berbahasa Jawa Taman Budaya Yogyakar- 
ta (terbit tahun 2004). Pada tahun 2009 novelnya yang berjudul Trah mendapat Anugerah Sastra Rancage oleh Yayasan Budaya Rancage.

\section{Masyarakat yang dituju}

Atas dalam novel Trah menceritakan tentang kondisi sosial budaya di Purworejo. Masyarakat yang dituju pengarang dalam novelnya merupakan masyarakat Jawa yang hidup didaerah pedesaan dengan mata pencaharian sebagian besar menjadi petani. Bagaimana para petani di desa yang memiliki lahan luas, akan tetapi seiring berjalannya waktu lahan tersebut harus dibagi-bagikan untuk anaknya. Kondisi perekonomian yang sulit, dan semakin sulitnya mencari pekerjaan meskipun pendidikan cukup tinggi, sehingga orang-orang lebih mengandalkan warisan dari orang tuanya dan tidak bisa berkembang. Selain itu, Atas juga menggambarkan kehidupan para buruh tani dan pengangguran, seperti kutipan berikut ini.

"Mau esuk isih matun bareng aku nang sawahe Bu Carik. Pancen pamit nek sore ora bisa lunga nyambut gawe marga dijaluki tulung Yu Darsih apek krambil. Ora ngira nek arep nemoni kedadeyan kaya ngono." (Danusubroto 2008:8)

Kutipan tersebut menunjukkan bahwa tokoh Pardi dan temannya yang bernama Rukiban bekerja untuk menyiangi rumput di sawah, yang artinya dia merupakan buruh tani. Selepas itu dia memetik kelapa di rumah Yu Darsih, dalam cerita ini Rukiban kemudian diceritakan meninggal karena terjatuh dari pohon kelapa. Padahal Rukiban merupakan tulang punggung keluarga dan anaknya masih kecil-kecil. Rukiban merupakan keluarga yang kurang mampu, biaya pemakamanpun ditanggung bersama.

Penceritaan masyarakat semacam ini banyak terdapat dalam novel Trah, Atas menggambarkan masyarakat yang bekerja sebagai buruh tani, namun gajinya tidak cukup untuk memenuhi kebutuhan sehari-hari sehingga harus bekerja serabutan untuk memenuhi kebutuhan keluarganya. Selain itu juga diceritakan bahwa menjadi buruh tani semakin susah karena adanya modernisasi, sehingga banyak digunakan alat-alat modern untuk mengelola sawah, seperti traktor dsb. Banyak juga masyarakat desa yang tidak mau lagi menjadi buruh tani, anak-anak muda tidak mau lagi bekerja di sawah dan memutuskan merantau menjadi buruh pabrik.

Novel Trah juga menceritakan tentang kehidupan pelacur yang menjadi tokoh utama dalam novel ini. Tokoh Tilarsih dalam novel ini adalah seorang perempuan cantik yang nekat pergi ke kota dengan modal ijasah SMP.

Tilarsih, putune Mbah Mardiyah, pancen wektu saiki lagi kanggo critan. Bocah wadon mau lungane saka ndesa ora sangu ijasah dhuwur, mbiyen mung tamat SMP. Neng ndesa melu nggabung dadi biduan orkes ndangdhut. Nalika isih dadi penyanyi kepetung lumayan, nanging banjur ngilang lan jare lunga mranto menyang kutha. Lebar panen kepungkur, Pawiro crita nek Tilarsih neng kutha dadi bocah nakal. (Danusubroto 2008:12)

Tokoh Tilarsih pergi ke kota untuk menjadi biduan, tetapi malah ditipu dan menjadi wanita penghibur. Hal ini disebabkan Tilarsih tidak memiliki pendidikan yang cukup dan berasal dari keluarga kurang mampu.

Masyarakat semacam inilah yang Atas gambarkan dalam novelnya, bagaimana tuntutan ekonomi dan kesenjangan sosial menyebabkan masalah-masalah sosial, terlebih lagi untuk masyarakat pedesaan. Minimnya pendidikan, sarana prasarana, susahnya lapangan pekerjaan, dan modernisasi menyebabkan mereka menghalalkan segala cara atau memilih hidup dalam kekurangan. Masyarakat yang dituju oleh Atas terpengaruh oleh masyarakat di sekitar pengarang, dimana Atas memang berasal dari keluarga kurang mampu.

\section{Fakta Sosial dalam Novel Trah}

Fakta sosial dalam karya sastra berasal dari pandangan bahwa sastra merupakan cermin masyarkat. Fakta dan permasalahan sosial yang terdapat di dalam karya sastra berasal dari pengamatan pengarang tentang kehidpan di sekitarnya. Masalah-masalah tersebut kemudian diangkat dan diolah menjadi sebuah cerita.

\section{Kemiskinan}

Kemiskinan merupakan suatu keadaan dimana seseorang mengalami kesusahan atau ketidakmampuan dalam pemenuhan kebutuhan primer. Kemisikinan dalam novel Trah dipaparkan sebagai berikut ini.

Wektu semana, marga Mbah Mardiyah wis randha lan miskin uripe, mula ora saguh mrgati Tlarsih mbacutakesekolah nganti dhuwur. Putune mung bisa tamat SMP banjur nganggur, lan neng ngomah supaya ngancani mbahne. (Danusubroto 2008:33)

Kutipan tersebut menunjukkan bagaimana kondisi perekonomian tokoh yang bernama Tilarsih, yang hidup dalam keadaan serba pas-pasan. Tokoh Tilarsih bisa dikatakan merupakan anak yatim piatu, karena ibunya meninggal ketika dia masih kecil dan ayahnya pergi keluar pulau dan menikah lagi. Sehinga sejak kecil Tilarsih tinggal bersama dengan kakek neneknya. Sayangnya kakeknya juga meninggal ketika di berusia kurang dari lima tahun. Neneknya yang merupakan janda tidak mampu menyekolahkan Tilarsih sehingga dia hanya sekolah sampai SMP. Tilarsih kemudian ditawari untuk menjadi biduan di kampungnya.

Mbah Mardiyah dalam novel Trah diceritakan memiliki lahan atau kebun kecil, sebagai sumber utama penghasilannya untuk menghidupi dirinya dan Tilarsih. Gambaran semacam ini diceritakan cukup jelas dalam novel, bagaimana kondisi pedesaan di tengah modernisasi dan pembangunan yang tidak merata, menyebabkan naiknya angka kemiskinan. Sehingga anak-anak muda susah untuk mendapatkan pedidikan 
dan angka pengangguran semakin bertambah. Karena tuntutan ekonomi juga akhirnya Tilarsih terjebak di dunia pelacuran. Selain itu, kemiskinan dalam novel ini juga digambarkan dalam kehidupan para buruh tani dan pekerja serabutan, seperti kutipan berikut ini.

\section{Pengangguran}

Pengangguran merupakan sebutan untuk orang yang tidak mempunyai pekerjaan maupun penghasilan. Dengan adanya pengangguran dapat menyebabkan terjadinya masalah-masalah sosial, seperti kemiskinan, dsb. Pengangguran bisa terjadi karena jumlah lapangan kerja tidak sebanding dengan pencari kerja. Seperti kutipan berikut ini.

Mula ora ana wong maido, Jumari sing wis tamat STM, trima neng desa dadi buruh. Apa maneh mung Jumari, Mas Sumantri karo Priyambodo, putrane Pak Mantri Tani sing wis dadi sarjana, lonthang-lanthung. Jare saben nglamar penggawean ora tau ketampa. Kamangka wong urip butuh mangan, nyandhang, lan liya-liyane. Nek nganggur, sapa sing makani lan nyandhangi? (Danusubroto 2009:10)

Kutipan tersebut menunjukkan bagaimana susahnya mencari lapangan pekerjaan yang sesuai dengan jenjang pendidikan. Bukan hanya lulusan SMA yang susah mencari pekerjaan, tapi juga para sarjana. Kecocokan dalam mencari pekerjaan adalah permasalahan utama dalam novel ini, sedangkan dengan tidak adanya kecocokan, maka jumlah angka pengangguran akan semakin tinggi. Sedangkan tuntutan hidup cukup tinggi, dan membutuhkan kebutuhan primer dan sekunder. Sekalipun berasal dari keluarga yang perekonomiannya bisa dikatakan mampu, masalah penggangguran juga termasuk cukup serius. Karena dengan pemasukan yang sama sedangkan biaya hidup yang ditanggung bertambah, tentunya dapat menyebabkan turunnya kemampuan ekonomi. Sehingga masalah pengangguran menjadi cukup pelik, terlebih lagi apabila ada anggota keluarga yang masih menganggur dan meminta untuk dinikahkan.

Penceritaan Danusubroto mengenai pengangguran bisa jadi bersadar pengamatannya terhadap kondisi perkonomian Indonesia tahun 2008. Pada tahun 2008, terjadi krisis keuangan dunia yang disebabkan krisis yang melanda Amerika Serikat pada tahun 2007. Selain berdampak pada ekspor impor, Asosiasi Pengusaha Indonesia (Apindo) memperkirakan selama krisis setidaknya sekitar satu juta pekerja di Indonesia kehilangan pekerjaan terimbas dampak krisis global. Krisis tersebut meyebabkan ekonomi AS pun memasuki era resesi yang memicu krisis ekonomi dan keuangan global. Dan, negara seperti Indonesia pun tak lepas dari ekses resesi global tadi. Tindakan banyak perusahaan memPHK karyawan yang mencapai satu juta pekerja adalah bukti, Indonesia memasuki era krisis (Bank Indonesia 2010:1,3).

Kondisi tersebut tidak lepas dari pengamatan Atas, ketika para pengamat politik dan ekonomi mengamati bagaimana dampak krisis tersebut pada indeks saham, angka kemiskinan, pengangguran, dsb. Atas mengungkapkan fakta bagaimana kondisi masyarakat pedesaan yang kala itu perekonomiannya bergantung dari sekotor pertanian. Meskipun dalam novel tidak disebutkan secara langsung bahwa pengangguran dan kemiskinan yang terjadi dikarenakan krisis ekonomi yang melanda Indonesia pada masa itu, namun dilihat dari tahun penerbitan dan latar belakang Atas yang merupakan seorang jurnalis, dapat dipahami secara tidak langsung Atas menceritakan bagaimana kondisi sulit yang dialami masyarakat pada masa itu. Atas juga menggunakan kata 'rusak' untuk menggambarkan kondisi sosial masyarakat, seperti kutipan berikut ini.

Jebul jagat kuwi wis rusak banget. Apa ya papan kana pancen dadi jagate wong rusak? Nyatane petugas, pegawe kantor, tukang becak, kuli bangunan, bapakbapak sing nganggo sedan, uga padha kober ngluyur mrana (Danusubroto 2008:116).

Kata 'rusak banget' pada kutipan tersebut mengacu pada kehidupan di lokalisasi, bagaimana orang-orang dari pekerja kasar bahkan sampai pejabat pergi ke lokalisasi. Kata 'rusak banget' digunakan untuk menggambarkan kondisi masyarakat yang mencari kesenangan dan hiburan dengan hal-hal yang negatif, dan fakta tersebut di pengaruhi oleh kondisi perekonomian yang memburuk, membuat tuntutan kehidupan semakin tinggi, dan para pekerja tersebut stress dan butuh hiburan. Atas dalam prolog novel Trah, menceritakan tentang kondisi perekonomian di desa tersebut, yang kemudian menjadi faktor pendukung tokoh Tilarsih bekerja sebagai pelacur, maupun tokoh Bagus yang pergi dari rumah.

Fakta-fakta sosial yang dihadirkan Atas dalam novelnya, tentu saja berdasarkan pengamatan dan sudut pandang Atas. Fakta tersebut kemudian diolah dan dihadirkan dalam karya sastra. Disini fungsi sastra sebagai cermin masyarakat dapat dikatakan berhasil karena Atas berhasil menghadirkan bagaimana kondisi masyarakat kecil yang terkena imbas krisis ekonomi pada masa itu. Akan tetapi fakta-fakta tersebut juga harus dipilah lagi, karena dalam proses pengolahan tentu saja mendapatkan pengaruh dari sudut pandang pengarang dan dramatisasi cerita.

\section{Pelacuran}

Pelacuran adalah hubungan seksual yang dilakukan oleh siapa saja, dengan imbalan uang. Dalam kehidupan manusia, pelacuran dipandang negatif, dan mereka yang menyewakan atau menjual tubuhnya sering dianggap sebagai sampah masyarakat yang nista dan hina.

Novel Trah menceritakan banyak hal tentang pelacuran, novel ini mengangkat permasalahan seperti alasan seseorang menjadi pelacur, bagaimana kerasnya kehidupan di lokalisasi dan yang lebih berfokus kepada bagaimana kehidupan para pelacur itu sendiri. Novel ini bercerita tentang Tilarsih yang berasal dari keluarga kurang mampu, dan ditipu oleh Atun yang menjanjikannya untuk menjadi biduan terkenal. Tetapi ternyata 
Atun merupakan sindikat penjual perempuan dan menjual Tilarsih kepada germo.

Dheweke saiki nembe mudheng menawa awake wis diedol dening Atun kaya dene budhak. Banjur dijlomprongake supaya nyambut gawe gelem ngladeni nepsu setan anggon-anggone wong lanang thukmis. Pancen sakdurunge kejlungup tekan papan mau, dheweke sering krungu menawa ana sindikat penjual wanita. Apa Tante Kori lan Atun kepetung sindikat mau? Apa dheweke pancen bener wis ketlikung dening jaringan sindikat penjual wanita kang pakaryane nggolek bocah enom-enom ayu, banjur bocah-bocah mung diedol kanggo nyukupi butuhe wong lanang thukmis? (Danusubroto 2008:62)

Rendahnya tingkat pendidikan dan juga faktor ekonomi menjadi salah satu alasan kenapa Tilarsih terjebak dalam dunia pelacuran. Alasan-alasan seperti inilah yang coba diangkat oleh Atas dalam novelnya. Untuk menunjukkan sisi bahwa tidak selalu mereka yang menjadi pelacur itu atas dasar keinginannya pribadi. Faktor pendidikan, ekonomi, terlebih lagi lapangan pekerjaan sangat mempengaruhi. Bisa jadi juga penipuan dan sindikat penjual wanita menjadi salah satu penyebab mereka menjadi pelacur.

\section{Harta Warisan}

Harta warisan adalah masalah yang cukup populer diangkat dalam karya sastra. Novel ini menceritakan tentang harta warisan yang justru menjadi salah satu penyebab kemiskinan. Atas dalam novel ini menceritakan dengan cukup apik, bagaimana masalah harta warisan menjadi salah satu alasan masyarakat desa tersebut tidak berkembang dan terjebak dalam kemiskinan.

"Nanging saiki rak dadi bocah kumalungkung, ta? Gedhe endase awit rumangsa dadi anake wong sugih, mula yen duwe kekarepan kudu keturutan. Sedulure sing dadi korban. Kaya awakmu, coba pikiren, saiki kejibah nerusake usaha wong tuwa nglakokake gilingan pari. Tata lair, awakmu kaya bos. Nyatane kowe mung buruh marang wong tuwa. Yen buruh malah cetha ana opahe. Nek kowe, upahmu apa?" kandhane Karjo. "Saiki kok bandhingake karo Gunadi sing saben dinane mung dolan, awit nyatane jare kuliah ya ora nggenah. Yen kowe nyambut gawe, sedina digaji pira neng ibumu? Apa seimbang karo keselmu? Apa sebandhing karo dhuwit sing diwenehake Gun? Pikiren, Gus." (Danusubroto 2008:120-121)

\section{Fungsi Sosial Sastra}

Ian watt menyebutkan karya sastra dapat berfungsi sebagai hiburan maupun sebagai nasehat. Fungsi sosial novel Trah, antara lain sebagai berikut.

\section{Hiburan}

Fungsi yang pertama adalah sebagai hiburan, dimana karya sastra dipandang sebagai pengatur irama hidup. Alur cerita yang ditulis oleh Atas dalam novel
Trah dapat dilihat sebagai bentuk hiburan, karena alur tersebut membuat pembaca tertarik dan penasaran dengan kelanjutan cerita. Penggambaran Atas akan suasana alam pendesaan Jawa pada waktu tersebut, juga termasuk fungsi sastra sebagi hiburan. Karena pembaca dapat memahami bagaimana kondisi alam pada masa itu, yang tentram dan damai.

Wektu kuwi dina Senen, kebener lagi ramene Pasar Purwodadi. Nanging kerameyane pasar ndesa yen nuju dina pasaran, ora kaya wetara sepuluh tau kepungkur nalika Tilarsih isih cilik. Mbiyen, kabeh bango pasar yen dina pasaran mesthi kebak bakul. Nanging saiki, senajan dina pasaran, bangone padha kotong.

Sepine pasar ndesa marga mobil angkutan akeh banget, mula wong sing arep tetuku milih menyang pasar kutah. Pasar ndesa wis akeh banget sing mati. Bakul cilik uga akeh sing sambat awit bisa adol nanging ora bisa tuku maneh. Reregan terus mundhak (Danusubroto 2008:205).

Kutipan tersebut menunjukkan bagaimana kondisi pasar pada masa sekarang. Atas tidak hanya menggambarkan kondisi masyarakat pada masa itu, tetapi juga perubahn-perubahan yang terjadi setelahnya. Bagaimana modernisasi dan kemajuan ditanggapi oleh masyarakat dan menciptakan perubahan. Penggambaran kondisi yang semacam ini, dapat membuat pembaca merasa terhibur dengan membayangkan bagaimana kondisi pada masa itu yang sudah mulai ramai namun tidak sepadat sekarang.

\section{Nasehat}

Sastra sebagai nasehat atau ajaran, cukup banyak ditemukan dalam novel ini. Novel ini menceritakan kultur budaya masyarakat Jawa pada masa itu yang penuh dengan nilai luhur.

Tilarsih meneng, Mbah Mardiyah nerusake omong. "Ndhuk, sedulur bisa pedhot kuwi sepisan marga bandha. Coba, yen sing siji sugih, liyane mlarat. Sing sugih dicedhaki sing mlarat, wedi menawa nganti dijaluki. Semana uga kang mlarat arep nyedhak sing sugih, samar yen didakwa arep njejaluk. Pindhone sedulur bisa pedhot marga pangkat. Sing siji pangkate dhuwur, liyane trima buruh tani. Sing buruh tani arep sowan menyang omahe kang duwe pangkat dhuwur wedi, semana uga sing pangkate dhuwur arep teka menyang omahe si buruh tani, ora kober. Ping telu, sedulur bisa pedhot marga kepinteran. Siji dadi sarjana, liyane buta huruf, yen kebener ketemu banjur arep crita apa? Mesti ora gambuh. Menawa arep crita barengbareng mesti ora cocok marga wis beda carane mikir. Perkara telu kuwi sing marakake sedulur bisa pedhot sesambungane. Mula banjur ana tetembungan, jaman saiki akeh sedulur dadi wong liya, nanging wong liya malah dadi sedulur." (Danusubroto 2008:183)

Kutipan tersebut menunjukkan bagaimana Mbah Mardiyah mengajari cucunya tentang kehidupan sosial, 
bagaimana hubungan dengan saudara yang dapat dipisahkan oleh harta benda. Suatu hal yang sangat marak terjadi belakangan ini. Ketika ada saudara yang lebih kaya, yang miskin takut untuk mendekat, takut dianggap meminta-minta. Sedangkan yang kaya juga merasa khawatir jika sadudaranya yang miskin akan meminta harta bendanya. Bahkan cerita-cerita semacam ini juga marak dalam drama-drama yang ditayangkan di televisi. Atas melalui dialog tersebut ingin menyadarkan pembaca bahwa hubungan saudara tidak baik diputuskan hanya karena harta benda maupun status sosial.

\section{Kritik Sosial}

Fungsi yang terakhir adalah karya sastra sebagai bentuk kritik. Novel Trah yang ditulis oleh Atas secara sepintas terlihat hanya menceritakan tentang usaha Tilarsih untuk memperbaiki hidupnya karena bekas pelacur. Apabila ditinjau dari profesionalisme dan masyarakat yang dituju oleh pengarang, Atas menyampaikan kritiknya dalam novel ini secara tidak langsung.

Atas merupakan seorang jurnalis, yang biasa menuliskan karya sastra dari apa yang diamati di lingkungan sekitarnya. Masyarakat yang dituju oleh Atas dalam novel ini adalah petani, pengangguran, pelacur, dsb., dan disaat yang bersamaan novel tersebut ditulis saat Indonesia sedang terkena dampak dari krisis ekonomi global yang disebabkan Amerika. Krisis ini membuat banyak pekerja yang di PHK, susah mencari pekerjaan, dan naiknya angka kemiskinan. Hal-hal tersebut yang melatar belakangi Atas menyampaikan kritik dalam novelnya, terdapat dua kritik yang pertama kritik sosial, kedua kritik terhadap pemerintah.

Kritik terhadap pemerintah dapat dilihat dari kutipan berikut ini.

"Kapan negarane dhewe bisa reja? Wargane bisa nyambut gawe lan duwe kasil sempulur, padha bisa oleh pangan sing cundhuk karo kapinterane?"pitakone Pak Mantri Tani sing katon getun awit anake lanang isih padha nganggur, kamangka wis padha njaluk bojo. Nek ngrungokake pengudarasane Pak Mantri Tani sing kaya mangkono, ora ana kang bisa wangsulan. Marga Pak Mantri Tani sing kepetung wong cukup wae sambate tanpa kendhat kaya grantang. Nek wis kaya mangkono banjur wong kaya Rukiban olehe sambat arep kepiye? Mula ora ana sing maido menawa anake lanang, senajan wis tamat sekolah tetep urip neng ndesa, trima dadi buruh. (Danusubroto 2008:10)

Kutipan tersebut merupakan bentuk kritik Atas terhadap pemerintah, karena pendidikan nyatanya tidak mampu menjamin untuk mendapatkan pekerjaan dan tidak tersedianya lapangan kerja yang sesuai dengan pendidikan yang dimiliki. Ketidak merataan pembangunan juga menjadi salah satu bentuk kritik Atas secara tidak langsug dalam novel ini.

\section{SIMPULAN}

Berdasar hasil analisis konteks sosial pengarang, fakta dan fungsi sosial sastra dalam novel Trah karya Atas Danusubroto, maka dapat disimpulkan konteks sosial pengarang, terdiri dari biografi pengarang yang berisi riwayat hidup pengarang. Masyarakat yang ditu$\mathrm{ju}$, yaitu pandangan kehidupan Atas tentang masyarakat yang ditulis dalam novel tersebut dipengaruhi oleh pengamatan dan kebiasaan Atas menulis sesuatu yang dekat dengannya, masyarakat yang dituju Atas dalam novel Trah seperti petani, pengangguran, buruh tani, pelacur.

Fakta sosial dalam novel Trah terbagi menjadi dua, yang pertama fakta sosial yang ada di dalam cerita yaitu kemiskinan, pengangguran, pelacuran, dan harta warisan. Hal-hal tersebut disebabkan satu hal, yaitu masalah perekonomian, kemudian fakta-fakta yang terjadi di masyarakat pada tahun yang sama ketika novel tersebut ditulis, yaitu saat Indonesia sedang terkena imbas dari krisis ekonomi global yang disebabkan krisis ekonomi di Amerika. Fenomena ini tentunya menarik perhatian banyak pihak, termasuk Atas dan menyajikannya dalam novel Trah, dimana dihadirkan gambaran kehidupan masyarakat pedesaan yang terpinggir dan bagaimana krisis ekonomi mempengaruhi hidup mereka. Fungsi sosial yang ada dalam novel Trah, yaitu sebagai hiburan, nasehat, dan kritik.

Saran yang dapat diberikan dalam penelitian ini adalah novel Trah dapat dijadikan kajian dan diskusi dalam sarasehan budaya tentang masyarakat Jawa. Selain itu juga dapat dijadikan bahan referensi bagi peneliti dan sastrawan tentang gaya penulisan karya sastra Jawa modern yang kental unsur budaya Jawa.

\section{DAFTAR PUSTAKA}

Bank Indonesia. 2010. Krisis Global dan Penyelamatan Sistem Perbankan Indonesia. Jakarta: Bank Indonesia.

Damono, Sapardi Djoko. 1979. Sosiologi Sastra: Sebuah Pengantar Ringkas. Jakarta. Pusat Pembinaan dan Pengembangan Bahasa.

Damono, Sapardi Djoko. 2002. Pedoman Penelitian Sosiologi Sastra. Jakarta: Pusat Bahasa DEPDIKNAS.

Danusubroto, Atas. 2008. Trah. Yogykarta: Narasi.

Ratna, Nyoman Kunta. 2010. Metode Penelitian Sastra. Yogyakarta: Pustaka Pelajar.

Supriyanto, Teguh. 2008. Teks dan Ideologi. Semarang: Unnes Press.

Suseno, Frans Magnis. 2003. Etika Jawa. Jakarta: Gramedia. 